\title{
Detection of Bovine Coronavirus by Conventional Reverse Transcription Polymerase Chain Reaction
}

\author{
Amauri Alcindo Alfieri, Alice Fernandes Alfieri, and Elisabete Takiuchi
}

\begin{abstract}
Bovine coronavirus $(\mathrm{BCoV})$ is an economically significant cause of enteric and respiratory diseases in cattle throughout the world. $\mathrm{BCoV}$ is a known cause of neonatal calf diarrhea, winter dysentery in adult cattle, and respiratory disorders in cattle of all ages. In this chapter, we describe a simple and efficient protocol for total nucleic acids extraction to be used in conventional RT-PCR assay. This is a technique used routinely in our virology laboratory to detect $\mathrm{BCoV}$ from stool and nasopharyngeal samples of cattle.
\end{abstract}

Key words Bovine coronavirus, RT-PCR, Clinical diagnosis, Stool samples, Nasopharyngeal samples

1 Introduction

Bovine coronavirus $(\mathrm{BCoV})$ is a member of the order Nidovirales, Coronaviridae family, which was recently classified as member of the specie Betacoronavirus 1 in the genus Betacoronavirus [1].

$\mathrm{BCoV}$ are frequently circulating in cattle farms worldwide, causing both enteric and respiratory disease in calves and adult cattle [2]. Because the respiratory and enteric disorders are similar to the other infectious diseases, a specific test is needed for a conclusive diagnosis of $\mathrm{BCoV}$ infection. Besides sensitive tests are required to detect $\mathrm{BCoV}$ especially at early or late stages of disease when they have low levels of viral shedding.

The current methods used for the diagnosis of $\mathrm{BCoV}$ consist mostly of the detection of viral RNA by conventional (RT-PCR) and real-time reverse transcription polymerase chain reaction (qRT-PCR) [3-6]. Recently, isothermal nucleic acid amplification techniques, such as recombinase polymerase amplification (RPA) assay and reverse transcription loop-mediated isothermal amplification (RT-LAMP), have been developed for rapid detection of $\mathrm{BCoV}[7,8]$. However, there are still few reports evaluating 
these new assays in large-scale epidemiological studies of $\mathrm{BCoV}$ infections.

In this chapter, we describe a sensitive and specific conventional RT-PCR assay that has been successfully applied for diagnosis of both enteric and respiratory bovine coronaviruses [9-12].

\section{Materials}

\subsection{RNA Extraction}

2.2 Clinical Samples (See Note 1)
1. Sodium dodecyl sulfate (SDS) $10 \%$.

2. Ultrapure phenol-chloroform-isoamyl alcohol $(25: 24: 1, \mathrm{v} / \mathrm{v})$ (Invitrogen).

3. Silicon Dioxide $\left(\mathrm{SiO}_{2}\right)$ (Sigma).

4. Guanidine isothiocyanate (GuSCn) (Invitrogen).

5. Acetone PA.

6. Ethanol solution $70 \%$ (in water).

7. Diethylpyrocarbonate (DEPC)-treated water (Invitrogen).

8. EDTA.

9. Hydrochloric acid $32 \%-\mathrm{HCl} 32 \%$ (Sigma).

10. Triton X-100 (Invitrogen).

11. Tris (hydroxymethyl)aminomethane (TRIS).

12. Lysis buffer L6.

13. Washing buffer L2.

Fecal samples: The samples were prepared either as $10 \%(\mathrm{w} / \mathrm{v})$ suspensions of solid or semisolid feces in $0.01 \mathrm{M}$ phosphate-buffered saline (PBS) pH 7.2 (137 mM NaCl; $3 \mathrm{mM} \mathrm{KCl} ; 8 \mathrm{mM}$ $\left.\mathrm{Na}_{2} \mathrm{HPO}_{4} ; 15 \mathrm{mM} \mathrm{KH}_{2} \mathrm{PO}_{4}\right)$ or as $50 \%(\mathrm{v} / \mathrm{v})$ suspensions of liquid feces in $0.01 \mathrm{M} \mathrm{PBS}$ and centrifuged at $3000 \times \mathrm{g}$ for $15 \mathrm{~min}$ at $4{ }^{\circ} \mathrm{C}$. The supernatant is transferred to a sterile tube. Separate an aliquot of $400 \mu \mathrm{l}$ for RNA extraction.

Nasopharyngeal swab samples: the tip of swab containing nasopharyngeal secretions is soaked in $1 \mathrm{ml}$ of sterile saline solution or $0.01 \mathrm{M}$ PBS. The swab is vortex-mixed for $15 \mathrm{~s}$ and then discarded. Centrifuge at $3000 \times g$ for $15 \mathrm{~min}$ at $4{ }^{\circ} \mathrm{C}$. The supernatant is transferred to a sterile tube. Separate an aliquot of $450 \mu \mathrm{l}$ for RNA extraction.

Silica suspension is prepared as described by Boom et al. [13] with minor modifications.

1. Suspend six grams of silicon dioxide $\left(\mathrm{SiO}_{2}\right)$ in $50 \mathrm{ml}$ of sterile distilled water in a glass graduated cylinder.

2. Slowly stir and keep at rest at room temperature for $24 \mathrm{~h}$ for the silica coarse particles to settle.
Process
2.3.1 Silica Hydration

\section{Reagent and Solutions Used for RNA Extraction}

Process 
3. Remove and discard $43 \mathrm{ml}$ of the supernatant from the top with vacuum suction or pipette. Then, resuspend the silica by adding $50 \mathrm{ml}$ of sterile distilled water.

4. Slowly stir and leave for $5 \mathrm{~h}$.

5. Remove and discard $44 \mathrm{ml}$ of the supernatant from the top with vacuum suction or pipette.

6. Add $60 \mu \mathrm{l}$ of concentrated $\mathrm{HCl}(32 \% \mathrm{w} / \mathrm{v})$ to adjust $\mathrm{pH}$ $(\mathrm{pH}=2.0)$.

7. Mix the final content (resulting suspension of silica coarse) and divide into small aliquots $(4 \mathrm{ml})$ into glass bottles with autoclavable cap, tightly closed.

8. Sterilize in an autoclave at $121^{\circ} \mathrm{C}$ for $20 \mathrm{~min}$. Store at $4{ }^{\circ} \mathrm{C}$.

\subsection{Prepare of Lysis Buffer L6 and Washing Buffer L2}

\subsection{1 $0.1 \mathrm{M}$ Tris- $\mathrm{HCl}$ (pH 6.4)}

2.4.2 0.2 M EDTA (pH 8.0)

2.4.3 Lysis Buffer L6

2.4.4 Washing Buffer L2
Prepare the following fresh solutions before preparing lysis buffer:

Dissolve $2.67 \mathrm{~g}$ of TRIS in $180 \mathrm{ml}$ of distilled water. Add $\mathrm{HCl}$ $32 \%$ to adjust the $\mathrm{pH}$ to 6.4 . Stir vigorously on a magnetic stirrer. Fill up to volume $220 \mathrm{ml}$ with distilled water and set aside at room temperature until use.

Add $1.86 \mathrm{~g}$ of EDTA in $15 \mathrm{ml}$ of distilled water. Adjust the $\mathrm{pH}$ to 8.0 with $\mathrm{NaOH}$. Fill up to volume $25 \mathrm{ml}$ with distilled water and set aside at room temperature until use (see Note 2 ).

1. Dissolve $120 \mathrm{~g}$ of GuSCN in $100 \mathrm{ml}$ of $0.1 \mathrm{M}$ Tris- $\mathrm{HCl}$ $(\mathrm{pH} 6.4)$ in a beaker.

2. Add $22 \mathrm{ml}$ of a $0.2 \mathrm{M}$ EDTA solution ( $\mathrm{pH} 8.0$ ).

3. Add $2.6 \mathrm{~g}$ of Triton X-100.

4. Homogenize vigorously the solution (see Note $\mathbf{3}$ ).

5. Transfer the solution into a glass bottle with autoclavable cap.

6. Sterilize in an autoclave at $121{ }^{\circ} \mathrm{C}$ for $20 \mathrm{~min}$. Store at $4{ }^{\circ} \mathrm{C}$ (see Note 4).

1. Dissolve $120 \mathrm{~g}$ of GuSCN in $100 \mathrm{ml}$ of $0.1 \mathrm{M}$ Tris- $\mathrm{HCl}$ ( $\mathrm{pH}$ 6.4) in a beaker.

2. Homogenize vigorously the solution (see Note $\mathbf{3}$ ).

3 . Transfer the solution into a glass bottle with autoclavable cap.

4. Sterilize in an autoclave at $121^{\circ} \mathrm{C}$ for $20 \mathrm{~min}$. Store at $4^{\circ} \mathrm{C}$.

1. Moloney Murine Leukemia Virus Reverse Transcriptase (M-MLV RT), $200 \mathrm{U} / \mu \mathrm{l}$ (Invitrogen).

2. $5 \times$ First-Strand Buffer: $250 \mathrm{mM}$ Tris- $\mathrm{HCl}(\mathrm{pH} \mathrm{8.3)}, 375 \mathrm{mM}$ $\mathrm{KCl}, 15 \mathrm{mM} \mathrm{MgCl}$ (Invitrogen). 
2.6 Polymerase

Chain Reaction

\subsection{Semi-nested Polymerase Chain Reaction}

\section{$2.8 \mathrm{Gel}$ electrophoresis}

3. 0.1 M dithiothreitol (DTT) (Invitrogen).

4. $20 \mu \mathrm{M}$ reverse primer BCoV2: 5'-TGTGGGTGCGAGTT CTGC-3' (nt 940-957).

5. Deoxynucleotide triphosphates (dNTP) mix, $10 \mathrm{mM}$ each (Invitrogen).

6. DEPC-treated water (Invitrogen).

7. Thermocycler (Applied Biosystems).

1. Platinum TaqDNA polymerase, $5 \mathrm{U} / \mu \mathrm{l}$ (Invitrogen).

2. 10× PCR buffer (Invitrogen).

3. $50 \mathrm{mM} \mathrm{MgCl} 2$ solution (Invitrogen).

4. Deoxynucleotide triphosphates (dNTP) mix, $10 \mathrm{mM}$ each.

5. $20 \mu \mathrm{M}$ PCR forward primer, BCoVl: 5'-CGATGAGGCTA TTCCGAC-3' (nt 504-521).

6. $20 \mu \mathrm{M}$ PCR reverse primer, BCoV2: 5'-TGTGGGTGCG AGTTCTGC-3' (nt 940-957).

7. Thermocycler (Applied Biosystems).

1. Platinum TaqDNA polymerase, $5 \mathrm{U} / \mu \mathrm{l}$ (Invitrogen).

2. $10 \times$ PCR buffer (Invitrogen).

3. $50 \mathrm{mM} \mathrm{MgCl}$ solution (Invitrogen).

4. Deoxynucleotide triphosphates (dNTP) mix, $10 \mathrm{mM}$ each.

5. $20 \mu \mathrm{M}$ PCR forward primer, BCoV3: $5^{\prime}$-TTGCTAGTCTTGT TCTGGC-3' (nt 707-725).

6. $20 \mu \mathrm{M}$ PCR reverse primer, BCoV2: 5' -TGTGGGTGCGAG TTCTGC-3' (nt 940-957).

7. Thermocycler (Applied Biosystems).

1. $1 \times$ TRIS-borate-EDTA buffer pH 8.0 (0.89 M TRIS; 0.89 M boric acid; $0.02 \mathrm{M}$ EDTA).

2. UltraPure agarose (Invitrogen).

3. 123 bp DNA ladder markers (Invitrogen).

4. Ethidium bromide, $10 \mathrm{mg} / \mathrm{ml}$.

5. Agarose gel electrophoresis system (Apelex).

6. Power supply (Apelex).

7. Gel Documentation and Analysis System (Kodak).

8. Gel loading buffer $(6 \times)$ : $10 \mathrm{mM}$ Tris- $\mathrm{HCl}(\mathrm{pH} 7.6), 0.03 \%$ bromophenol blue, $0.03 \%$ xylene cyanol, $60 \%$ glycerol, and $60 \mathrm{mM}$ EDTA. 
3 Methods

\subsection{RNA Extraction}

The protocols described below are routinely used for clinical diagnosis of $\mathrm{BCoV}$ in cases of neonatal diarrhea, winter dysentery in adult cattle, and respiratory syndrome in cattle of all ages $[9,10]$.

Firstly, we describe how to obtain high quality nucleic acid total for routine molecular biology applications such as PCR and sequencing. We present an efficient and reproducible protocol for extracting RNA from feces and nasopharyngeal swab samples for $\mathrm{BCoV}$ diagnosis. This protocol, which we call phenol chloroform silica method, is based on cellular lysis and protein denaturation by SDS and phenol-chloroform-isoamyl alcohol treatment followed by nucleic acid purification by the guanidinium thiocyanate and silica [14]. Guanidinium thiocyanate is an excellent protein denaturant and hence very effective in inactivating nucleases. Using this protocol extraction it is possible to obtain high quality of RNA in the laboratory on a routine basis without the need for expensive commercial kits extractions.

For RT-PCR assay we chose the $\mathrm{N}$ gene because it is highly conserved among BCoV strains (see Note 5). Also it is known that the $\mathrm{N}$ protein is the most abundant antigen in coronavirus-infected cells because its RNA template is the smallest and it has the most abundant sgRNA (subgenomic RNA) during transcription [15]. This indicates that there is more available RNA for the $\mathrm{N}$ gene than for the other $\mathrm{BCoV}$ protein genes. Consequently, detection of the $\mathrm{N}$ gene RNA might be advantageous due to its high abundance in cells, facilitating a high sensitivity of the diagnostic technique.

1. Transfer $450 \mu \mathrm{l}$ of the fecal or nasopharyngeal suspensions into a $1.5 \mathrm{ml}$ polypropylene microtube. Include at least one positive control (HRT-18 cell culture-adapted BCoV Mebus strain or $\mathrm{BCoV}$ wild type strains) and one negative control (DEPCtreated water) in all the RNA extraction procedures.

2. Add $50 \mu \mathrm{l}$ of SDS $10 \%$ to a final concentration of $1 \%(\mathrm{v} / \mathrm{v})$.

3. Vortex for $5 \mathrm{~s}$ and incubate in a water bath at $56^{\circ} \mathrm{C}$ for $30 \mathrm{~min}$.

4. Add an equal volume $(500 \mu \mathrm{l})$ of ultrapure phenol-chloroformisoamyl alcohol to the microtube (see Note 6). For nasopharyngealswabsamplesthe treatmentwithphenol-chloroform-isoamyl alcohol (steps 2-5) are not performed.

5 . Vortex vigorously for $20 \mathrm{~s}$ to mix the phases and incubate in a water bath at $56^{\circ} \mathrm{C}$ for $15 \mathrm{~min}$.

6. Centrifuge at $10,000 \times \mathrm{g}$ for $10 \mathrm{~min}$ to separate the phases (upper aqueous phase, interface, and lower organic phase).

7. Use a micropipette to remove the aqueous phase (upper aqueous phase) into a new $1.5 \mathrm{ml}$ polypropylene microtube. Discard the 
microtube containing the interface (between the organic and aqueous phases) and organic phase (lower) (see Notes 7 and 8 ).

8. Add $30 \mu \mathrm{l}$ of hydrated silica ( see Note 9).

9. Add $900 \mu$ l of lysis buffer L6.

10. Vortex vigorously for $20 \mathrm{~s}$.

11. Place the microtubes in a rack and then incubate on an orbital shaker for $30 \mathrm{~min}$ at room temperature.

12. Briefly centrifuge the microtubes at $10,000 \times g$ for $30 \mathrm{~s}$ to pellet the silica resin.

13. Gently discard the supernatant by inversion ( see Note 10).

14. Add $500 \mu \mathrm{l}$ of ice-cold washing buffer L2 to the pellet. Vortex for $5 \mathrm{~s}$ to resuspend the silica pellet.

15. Briefly centrifuge the microtubes at $10,000 \times g$ for $30 \mathrm{~s}$ to pellet the silica resin.

16. Gently discard the supernatant by inversion ( see Note 10).

17. Once again, add $500 \mu \mathrm{l}$ of ice cold washing buffer L2 to the pellet. Vortex for $5 \mathrm{~s}$ to resuspend the silica resin. Repeat steps 13 and 14 .

18. Add $1 \mathrm{ml}$ of ice-cold ethanol $70 \%$ to the silica pellet. Vortex for $5 \mathrm{~s}$ to resuspend the silica pellet.

19. Briefly centrifuge the microtubes at $10,000 \times g$ for $30 \mathrm{~s}$ to pellet the silica resin.

20. Gently discard the supernatant by inversion ( see Note 10).

21 . Once again add $1 \mathrm{ml}$ of ice cold ethanol $70 \%$ to the pellet. Vortex for $5 \mathrm{~s}$ to resuspend the silica resin. Repeat steps 17 and 18.

22. Add $1 \mathrm{ml}$ of ice-cold acetone PA to the silica pellet. Vortex for $5 \mathrm{~s}$ to resuspend the silica pellet.

23. Centrifuge the microtubes at $10,000 \times g$ for $60 \mathrm{~s}$ to pellet the silica resin.

24. Gently discard the supernatant by inversion (see Note 10).

25. Place the microtubes with open lids in an inverted position over a clean filter paper to drain off the acetone excess.

26. Return the tubes to their normal position and keep them with lids open in a thermoblock (dry block heater) at $56{ }^{\circ} \mathrm{C}$ for $15 \mathrm{~min}$ to evaporate the acetone and dry the silica pellet.

27. Add $50 \mu \mathrm{l}$ of DEPC water. Vortex for $5 \mathrm{~s}$ to resuspend the silica pellet.

28. Incubate the microtubes with the lids closed in a water bath at $56^{\circ} \mathrm{C}$ for $15 \mathrm{~min}$ to elute nucleic acid from the silica resin. 


\subsection{Reverse Transcription (See Note 12)}

29. Centrifuge the microtubes at $10,000 \times g$ for $2 \mathrm{~min}$ to pellet the silica resin.

30. Remove the supernatant (nucleic acid eluted) with a micropipette into a new $0.5 \mathrm{ml}$ polypropylene microtube. Discard the microtube containing the silica pellet.

31. Store the eluted nucleic acid at -20 or $-80{ }^{\circ} \mathrm{C}$ until use (see Note 11).

1. Prepare a reverse transcription (RT) master mix in a volume sufficient for the number of reactions plus 1 in a sterile $1.5 \mathrm{ml}$ polypropylene microtube (label it "RT mix"). The volume of each RT reagent per reaction and the initial and final concentrations are shown in Table 1.

2. Vortex and centrifuge the tube briefly. Keep the microtube "RT mix" on an ice bath until use.

3. Label appropriately the $0.5 \mu$ l polypropylene microtubes with the sample identification.

4. Add to each microtube $5 \mu$ l of the corresponding sample (eluted RNA), $1 \mu$ l of reverse primer BCoV2 and $4 \mu \mathrm{l}$ of DEPC-treated water.

5. Incubate the microtubes at $97^{\circ} \mathrm{C}$ in a heat block for $4 \mathrm{~min}$.

6. Immediately after denaturing place on ice for at least $5 \mathrm{~min}$.

7. Add $10 \mu \mathrm{l}$ of "RT mix" solution into each microtube.

8. Vortex and centrifuge the tubes briefly.

9. In a thermocycler, incubate the microtubes at $42{ }^{\circ} \mathrm{C}$ for $30 \mathrm{~min}$, inactivate the transcription reaction at $95^{\circ} \mathrm{C}$ for $5 \mathrm{~min}$ and then chill the samples on ice bath.

10. Store the cDNA samples at $-20^{\circ} \mathrm{C}$ until use.

\section{Table 1}

Components of reverse transcription reaction

\begin{tabular}{llll}
\hline Reagent & $\begin{array}{l}\text { Volume per } \\
\text { reaction }(\boldsymbol{\mu l})\end{array}$ & $\begin{array}{l}\text { Volume mix for } N \\
\text { reactions }(\boldsymbol{\mu l})\end{array}$ & $\begin{array}{l}\text { Final } \\
\text { concentration }\end{array}$ \\
\hline $5 \times$ First strand buffer & 4 & $4 \times N$ & $1 \times$ \\
\hline $0.1 \mathrm{mM}$ DTT & 2 & $2 \times N$ & $0.01 \mathrm{mM}$ \\
\hline $10 \mathrm{mM}$ dNTP & 1 & $N$ & $0.5 \mathrm{mM}$ \\
\hline MMLV reverse transcriptase $(200 \mathrm{U} / \mu \mathrm{l})$ & 0.5 & $0.5 \times N$ & $100 \mathrm{U} / \mathrm{reaction}$ \\
\hline Water & 2.5 & $2.5 \times N$ & - \\
\hline Total volume of RT master mix & 10 & $10 \times N$ & - \\
\hline
\end{tabular}




\subsection{PCR Assay}

1. Prepare a PCR master mix in a volume sufficient for the number of reactions plus 1 in a sterile $1.5 \mathrm{ml}$ polypropylene microtube and label it "PCR mix." The volume of each PCR reagent per reaction and the initial and final concentrations are shown in Table 2.

2. Vortex and centrifuge the tube briefly. Keep the "PCR mix" on ice bath.

3. Dispense $42 \mu \mathrm{l}$ of the "PCR mix" into separate 0.5 polypropylene microtube and label the tubes accordingly.

4. Add $8 \mu \mathrm{l}$ of cDNA generated from the reverse transcription reactions into the correspondent tubes.

5 . Vortex and centrifuge the tubes briefly.

6. Run the PCR under the conditions shown in Table 3.

Table 2

Components of the PCR assay

\begin{tabular}{llll}
\hline Reagent & $\begin{array}{l}\text { Volume per reaction } \\
(\boldsymbol{\mu l})\end{array}$ & $\begin{array}{l}\text { Volume mix for } \mathbf{N} \\
\text { reactions }(\boldsymbol{\mu l})\end{array}$ & $\begin{array}{l}\text { Final } \\
\text { concentration }\end{array}$ \\
\hline $\mathrm{l} 0 \times$ First strand buffer & 7.5 & $7.5 \times N$ & $1.5 \times$ \\
\hline $\mathrm{MgCl}_{2}, 50 \mathrm{mM}$ & 2 & $2 \times N$ & $2 \mathrm{mM}$ \\
\hline $\mathrm{dNTP}, 10 \mathrm{mM}$ & 4 & $4 \times N$ & $0.8 \mathrm{mM}$ \\
\hline Reverse primer BCoV2 $(20 \mu \mathrm{M})$ & 1 & $\mathrm{~N}$ & $0.4 \mu \mathrm{M}$ \\
\hline Forward primer BCoVl $(20 \mu \mathrm{M})$ & 1 & $\mathrm{~N}$ & $0.4 \mu \mathrm{M}$ \\
\hline DNA polymerase $(5 \mathrm{U} / \mu \mathrm{l})$ & 0.5 & $0.5 \times N$ & $2.5 \mathrm{U} / \mathrm{reaction}$ \\
\hline Water & 26 & $26 \times N$ & - \\
\hline Total & 42 & $42 \times N$ & - \\
\hline
\end{tabular}

$N=$ number of $0.2 \mathrm{ml}$ tubes

Table 3

Conditions for PCR assay

\begin{tabular}{|lll}
\hline Step & Temperature $\left({ }^{\circ} \mathbf{C}\right)$ & Time \\
\hline 1. Heat activation & 94 & $4 \mathrm{~min}$ \\
\hline 2. Thermal cycling $(40$ cycles $)$ & & \\
\hline \multicolumn{1}{|c|}{ Denaturing step } & 94 & $1 \mathrm{~min}$ \\
\hline Annealing step & 55 & $1 \mathrm{~min}$ \\
\hline Extension & 72 & $1 \mathrm{~min}$ \\
\hline 3. Final extension & 72 & $7 \mathrm{~min}$ \\
\hline 4. Soak & 4 & $\infty$ \\
\hline
\end{tabular}


3.4 Semi-nested PCR Assay
1. Prepare a SN-PCR master mix in a volume sufficient for the number of reactions plus 1 in a sterile $1.5 \mathrm{ml}$ polypropylene microtube and label it "SN-PCR mix". The volume of each PCR reagent per reaction and the initial and final concentration are shown in Table 4. Vortex and centrifuge the tube briefly. Keep the "SN-PCR mix" on ice bath.

2. Dispense $47 \mu \mathrm{l}$ of the "SN-PCR mix" into separate 0.5 polypropylene microtube and label the tubes accordingly.

3 . Add $3 \mu$ of the first amplification product (PCR assay) into the correspondent tubes.

4. Vortex and centrifuge the tubes briefly.

5. Run the SN-PCR under the conditions shown in Table 5.

\section{Table 4}

Components of the semi-nested PCR assay

\begin{tabular}{lcll}
\hline Reagent & $\begin{array}{l}\text { Volume per reaction } \\
(\boldsymbol{\mu l})\end{array}$ & $\begin{array}{l}\text { Volume mix for } N \\
\text { reactions }(\boldsymbol{\mu l})\end{array}$ & $\begin{array}{l}\text { Final } \\
\text { concentration }\end{array}$ \\
\hline 10× First strand buffer & 5 & $5 \times N$ & $1 \times$ \\
\hline $\mathrm{MgCl}_{2}, 50 \mathrm{mM}$ & 2 & $2 \times N$ & $2 \mathrm{mM}$ \\
\hline $\mathrm{dNTP}, 10 \mathrm{mM}$ & 4 & $4 \times N$ & $0.8 \mathrm{mM}$ \\
\hline Reverse primer BCoV2 $(20 \mu \mathrm{M})$ & 1 & $\mathrm{~N}$ & $0.4 \mu \mathrm{M}$ \\
\hline Forward primer BCoV3 $(20 \mu \mathrm{M})$ & 1 & $\mathrm{~N}$ & $0.4 \mu \mathrm{M}$ \\
\hline DNA polymerase $(5 \mathrm{U} / \mu \mathrm{l})$ & 0.5 & $0.5 \times N$ & $2.5 \mathrm{U} / \mathrm{reaction}$ \\
\hline Water & 33.5 & $33.5 \times N$ & - \\
\hline Total & 47 & $47 \times N$ & - \\
\hline
\end{tabular}

$N=$ number of $0.2 \mathrm{ml}$ tubes

Table 5

Conditions for the semi-nested PCR assay

\begin{tabular}{|c|c|c|}
\hline Step & Temperature $\left({ }^{\circ} \mathrm{C}\right)$ & Time \\
\hline 1. Heat activation & 94 & $4 \mathrm{~min}$ \\
\hline \multicolumn{3}{|c|}{ 2. Thermal cycling ( 30 cycles) } \\
\hline Denaturing step & 94 & $1 \mathrm{~min}$ \\
\hline Annealing step & 55 & $1 \mathrm{~min}$ \\
\hline Extension & 72 & $1 \mathrm{~min}$ \\
\hline 3. Final extension & 72 & $7 \mathrm{~min}$ \\
\hline 4. Soak & 4 & $\infty$ \\
\hline
\end{tabular}




\subsection{Agarose Gel Electrophoresis}

6. After the run, analyze the SN-PCR products by gel electrophoresis. Alternatively, the products can be kept at $-20{ }^{\circ} \mathrm{C}$ for short-term storage.

1. Prepare $2 \%$ agarose gel by weighing out $2 \mathrm{~g}$ de agarose powder (for gel-tray dimension $14 \times 10 \times 0.7 \mathrm{~cm}$ ). Add it into a $250 \mathrm{ml}$ Erlenmeyer flask containing $100 \mathrm{ml} \mathrm{l} \times \mathrm{TBE}$ buffer.

2. Heat the agarose powder and electrophoresis buffer in a microwave oven until the agarose is completely melted.

3. Let agarose solution cool down to approximately $55^{\circ} \mathrm{C}$.

4. Add $5 \mu \mathrm{l}$ of ethidium bromide $(10 \mathrm{mg} / \mathrm{ml})$ to a final concentration of approximately $0.5 \mu \mathrm{g} / \mathrm{ml}$ ( see Notes 13-15).

5. Pour the solution into a sealed gel casting tray containing a gel comb.

6. Let sit for at least 30 min to solidify at room temperature (the solidified gel is opaque in appearance).

7. Remove the seal and comb. Place the gel and the plastic tray horizontally into the electrophoresis chamber with the wells at the cathode side.

8. Cover the gel with $1 \times$ TBE buffer.

9. Pipet $0.5 \mu \mathrm{l}$ of the DNA markers, $2 \mu \mathrm{l}$ of $6 \times$ gel loading dye and $8 \mu \mathrm{l}$ de water on a Parafilm sheet and mix well (pipetting up and down).

10. Pipet $10 \mu \mathrm{l}$ of the SN-PCR products and $2 \mu \mathrm{l}$ of $6 \times$ gel loading dye on a Parafilm sheet and mix well (pipetting up and down).

11. Pipet the samples into the wells.

12. Close the lid and connect the power leads on the electrophoresis apparatus.

13. Turn on power supply and apply a voltage of $80-100 \mathrm{~V}$. Run the gel for approximately $40 \mathrm{~min}$.

14. Turn off the power supply when the tracking dye has migrated a sufficient distance.

15. Remove the cover and retrieve the gel (see Note 16).

16. Place the gel on an ultraviolet transilluminator. Switch on the power of the gel photo-documentation machine (see Note 17).

17. Adjust the position of the gel and record the results. The size of the expected product for $\mathrm{BCoV}$ is $454 \mathrm{bp}$ and $25 \mathrm{l}$ bp for the first and second round of amplification, respectively. 
1. Clinical samples must be store at $4{ }^{\circ} \mathrm{C}$ for up to $48 \mathrm{~h}$ or frozen or $-80{ }^{\circ} \mathrm{C}$ for longer periods of time. The sensitivity of the PCR could be reduced if you repeat freezing and thawing of fecal samples. Store samples in multiple small aliquots to avoid repeated freeze-thaw cycles which accelerate degradation of nucleic acids, especially RNA.

2. The disodium salt of EDTA will not dissolve until the $\mathrm{pH}$ of the solution is adjusted to 8.0 by the addition of $\mathrm{NaOH}$.

3. Dissolution of GuSCN is facilitated by heating in a $60-65^{\circ} \mathrm{C}$ water bath under continuous shaking.

4. Buffers L6 and L2 are stable for at least 3 weeks at room temperature in the dark [13].

5. The three primers used in SN-PCR were designed from the highly conserved region of the $\mathrm{N}$ gene of the Mebus strain (GenBank accession number U00735).

6. Phenol is highly corrosive and can cause severe burns to skin. Personal protective equipment such as gloves, safety glasses, and a lab coat are essentials whenever working with phenol.

7. Be careful not to transfer any of the protein at the interphase.

8. Phenol and chloroform are considered hazardous chemicals by waste environment protection agencies and similar bodies around the world. Discard phenol-chloroform-isoamyl alcohol waste in a properly labeled container. For more information regarding hazardous waste management, contact your state hazardous waste agency.

9. Be careful to stir the tube containing hydrated silica before use to resuspend settled silica.

10. Be careful not to disturb the silica pellet when discarding the supernatant. Attention: GuSCN-containing waste should be collected in a strong alkaline solution $(10 \mathrm{~N} \mathrm{NaOH})$.

11. If you perform the RT-PCR on the same day, RNA extraction can be conserved at $4{ }^{\circ} \mathrm{C}$. For a longer conservation period, RNA must be stored at $-80^{\circ} \mathrm{C}$.

12. It is recommended to carry out the cDNA synthesis immediately after the RNA preparation. Being more stable than RNA, the storage of a first-strand cDNA is less critical.

13. Alternatively, the gel can be stained after DNA separation by electrophoresis. Place the gel into a container filled with $100 \mathrm{ml}$ of TBE running buffer and $5 \mu \mathrm{l}$ of ethidium bromide. Let the gel soak in this solution for 20-30 min. Wash the gel briefly with water before visualization under UV light. 
14. Ethidium bromide is mutagenic and moderately toxic and must be handled with care. Wear a lab coat, eye protection, and gloves when working with this chemical.

15. Liquid (running buffer) and solid (agarose gel, gloves, tips) waste contaminated with ethidium bromide must be managed as a hazardous waste. No liquids should be placed in the containers with the solid wastes. For more information regarding hazardous waste management, contact your state hazardous waste agency.

16. DNA will diffuse within the gel over time. Therefore, examination or photography should take place shortly after cessation of electrophoresis.

17. Exposure to UV light can cause severe skin and eye damage. Wear safety glasses and close the photography hood before turning on the UV transilluminator. Be certain to turn off UV light immediately after gel image is captured.

\section{Acknowledgments}

Alfieri, A.A. and Alfieri A.F. are recipients of the CNPq fellowships.

\section{References}

1. de Groot RJ, Baker SC, Baric R et al (2011) Family Coronaviridae. In: King AMQ, Adams MJ, Carstens EB et al (eds) Virus taxonomy, classification and nomenclature of viruses. Ninth report of the international committee on taxonomy of viruses. Elsevier Academic Press, Philadelphia, pp 806-828

2. Boileau MJ, Kapil S (2010) Bovine coronavirus associated syndromes. Vet Clin North Am Food Anim Pract 26:123-146. doi:10.1016/j. cvfa.2009.10.003

3. Takiuchi E, Stipp D, Alfieri AF et al (2006) Improved detection of bovine coronavirus $\mathrm{N}$ gene in faeces of calves infected naturally by a semi-nested PCR assay and an internal control. J Virol Methods 131:148-154. doi:10.1016/j. jviromet.2005.08.005

4. Decaro N, Elia G, Campolo M et al (2008) Detection of bovine coronavirus using a TaqMan-based real-time RT-PCR assay. J Virol Methods 151:167-171. doi:10.1016/j. jviromet.2008.05.016

5. Decaro N, Campolo M, Desario C et al (2008) Respiratory disease associated with bovine coronavirus infection in cattle herds in Southern Italy. J Vet Diagn Invest 20:28-32. doi:10.1177/104063870802000105
6. Amer HM, Almajhdi FN (2011) Development of a SYBR Green I based real-time RT-PCR assay for detection and quantification of bovine coronavirus. Mol Cell Probes 25:101-107. doi:10.1016/j.mcp.2011.03.001

7. Qiao J, Meng Q, Cai X et al (2011) Rapid detection of Betacoronavirus 1 from clinical fecal specimens by a novel reverse transcription loop-mediated isothermal amplification assay. J Vet Diagn Invest 24:174-177. doi:10.1177/ 1040638711425937

8. Amer HM, Abd El Wahed A, Ma S et al (2013) A new approach for diagnosis of bovine coronavirus using a reverse transcription recombinase polymerase amplification assay. J Virol Methods 193:337-340. doi:10.1016/j. jviromet.2013.06.027

9. Stipp DT, Barry AF, Alfieri AF et al (2009) Frequency of $\mathrm{BCoV}$ detection by a seminested PCR assay in faeces of calves from Brazilian cattle herds. Trop Anim Health Prod41:1563-1567.doi:10.1007/s11250-0099347-2

10. Takiuchi E, Aline AF, Alfieri AF et al (2009) An outbreak of winter dysentery caused by bovine coronavirus in a high-production dairy cattle herd from a tropical country. Trop 
Anim Health Prod 52:57-61. doi:10.1590/ s1516-89132009000700008

11. Fulton RW, Blood KS, Panciera RJ et al (2009) Lung pathology and infectious agents in fatal feedlot pneumonias and relationship with mortality, disease onset, and treatments. J Vet Diag Invest 21:464-477. doi:10.1177/104063870 902100407

12. Fulton RW, Step DL, Wahrmund J et al (2011) Bovine coronavirus (BCV) infections in transported commingled beef cattle and sole-source ranch calves. Can J Vet Res 75:191-199
13. Boom R, Sol CJ, Salimans MM et al (1990) Rapid and simple method for purification of nucleic acids. J Clin Microbiol 28:495-503

14. Alfieri AA, Parazzi ME, Takiuchi E et al (2006) Frequency of group A rotavirus in diarrhoeic calves in Brazilian cattle herds, 1998-2002. Trop Anim Health Prod 38:521-526. doi:10.1007/s11250-006-4349-9

15. Hofmann MA, Sethna PB, Brian DA (1990) Bovine coronavirus mRNA replication continues throughout persistent infection in cell culture. J Virol 64:4108-4114 